\title{
Isolation, culture, characterization and cryopreservation of stem cells derived from amniotic mesenchymal layer and umbilical cord tissue of bovine fetuses ${ }^{1}$
}

\author{
Loreta L. Campos ${ }^{2 *}$, Fernanda C. Landim-Alvarenga², Tatícia L. Ikeda², Bianca A. \\ Monteiro $^{2}$, Leandro Maia ${ }^{2}$, Camila P. Freitas-Dell'Aqua ${ }^{2}$ and Bruna De Vita ${ }^{2}$
}

\begin{abstract}
Campos L.L., Landim-Alvarenga F.C., Ikeda T.L., Monteiro B.A., Maia L., Freitas-Dell'Aqua C.P. \& De Vita B. 2017. Isolation, culture, characterization and cryopreservation of stem cells derived from amniotic mesenchymal layer and umbilical cord tissue of bovine fetuses. Pesquisa Veterinária Brasileira 36(3):278-286. Departamento de Reprodução Animal e Radiologia, Faculdade de Medicina Veterinária e Zootecnia, Universidade Estadual Paulista, Distrito de Rubião Júnior s/n, Botucatu, SP 18618-970, Brazil. E-mail: loreta_campos@yahoo.com.br

Stem cells are undifferentiated cells with a high proliferation potential. These cells can be characterized by their in vivo ability to self-renew and to differentiate into specialized cell lines. The most used stem cell types, in both human and veterinary fields, are the mesenchymal stem cells (MSC) derived from bone marrow and adipose tissue. Nowadays, there is a great interest in using stem cells derived from fetal tissues, such as amniotic membrane (AM) and umbilical cord tissue (UCT), which can be obtained non-invasively at delivery time. Due to the scarcity of studies in bovine species, the aim of this study was to isolate, characterize, differentiate and cryopreserve MSC derived from the mesenchymal layer of amniotic membrane (AM), for the first time, and umbilical cord tissue (UCT) of dairy cow neonates after assisted delivery (AD) and from fetus at initial third of pregnancy (IT) obtained in slaughterhouse. Cells were isolated by enzymatic digestion of the tissue fragments with $0.1 \%$ collagenase solution. Six samples of AM and UCT at delivery time and six samples of AM and UCT at first trimester of pregnancy were subjected to morphology evaluation, imunophenotype characterization, in vitro osteogenic, adipogenic and chondrogenic differentiation and viability analysis after cryopreservation. All samples showed adherence to plastic and fibroblast-like morphology. Immunocytochemistry revealed expression of $\mathrm{CD}$ 44, NANOG and OCT-4 and lack of expression of MHC II in MSC from all samples. Flow cytometry demonstrated that cells from all samples expressed CD 44, did not or low expressed CD 34 (AM: IT-0.3\%a, AD-3.4\% ${ }^{\mathrm{b}}$; UCT: 0.4\%, 1.4\%) and MHC II (AM: IT-1.05\% ${ }^{\mathrm{a}}$, AD-9.7\% UCT: IT- $0.7 \%^{\mathrm{a}}$, AD- $5.7 \%^{\mathrm{b}}$ ). They were also capable of trilineage mesenchymal differentiation and showed $80 \%$ viability after cryopreservation. According to the results, bovine AM and UCT-derived cells, either obtained at delivery time or from slaughterhouse, are a painless and non-invasive source of MSC and can be used for stem cell banking.
\end{abstract}

INDEX TERMS: Holstein cow, cell banking, MHC class II, fetal annexes, immunophetotype.

RESUMO.- [Isolamento, cultura, caracterização e criopreservação de células tronco derivadas de camada amniótica mesenquimal e de tecido do cordão umbili-

\footnotetext{
${ }^{1}$ Received on June 10, 2015.

Accepted for publication on February 22, 2016.

${ }^{2}$ Departamento de Reprodução Animal e Radiologia Veterinária, Faculdade de Medicina Veterinária e Zootecnia, Universidade Estadual Paulista "Júlio de Mesquita Filho" (Unesp), Botucatu, SP 18618-970, Brazil. *Corresponding author: loreta_campos@yahoo.com.br
}

cal de fetuses bovinos.] As células tronco mesenquimais (CTMs) estão presentes na maioria dos tecidos adultos e possuem grande capacidade de multiplicação. Quando cultivadas in vitro são capazes de se auto renovar e dar origem a novos tipos celulares. As células tronco mais utilizadas, tanto na medicina humana como na medicina veterinária são as células tronco mesenquimais derivadas da medula óssea e do tecido adiposo. Atualmente, uma grande tendência para a utilização de CTMs obtidas de tecidos fetais, 
como a membrana amniótica (MA), matriz extravascular do cordão umbilical (TCU) e sangue do cordão umbilical (SCU) pode ser observada, já que estas fontes podem ser colhidas no momento do parto por uma técnica não invasiva. Dessa forma, o objetivo deste estudo foi isolar, caracterizar, diferenciar e criopreservar CTMs obtidas de MA e TCU de fetos bovinos colhidos no momento do parto e de fetos do terço inicial da gestação em abatedouro-frigorífico. As células foram recuperadas por meio de digestão enzimática tecidual, realizada com solução de colagenase $0,1 \%$. Foram colhidas amostras de MA e TCU no momento do parto $(n=6)$ e de MA e TCU no terço inicial de gestação $(n=6)$, as quais foram submetidas às análises morfológicas, imunofenotípica por imunocitoquímica e citometria de fluxo, diferenciações in vitro nas linhagens osteogênica, adipogênica e condrogênica e ainda, avaliação da viabilidade após a criopreservação por citometria de fluxo. Todas as amostras dos diferentes grupos demonstraram adesão ao plástico e morfologia fibroblastóide. No ensaio imunocitoquímico todas as amostras foram imunomarcadas para CD44, NANOG e Oct-4, com ausência de marcação para MHC II. Na análise imunofenotipica por citometria de fluxo, todas as amostras apresentaram marcação para CD44, ausência de marcação para ou baixíssima expressão de CD34 (MA: TI$-0,3 \%^{\mathrm{a}}$, PA-3.4\% ${ }^{\mathrm{b}}$; TCU: TI- $0,4 \%, \mathrm{PA}-1.4 \%$ ) e nula ou baixa expressão de MHC II (MA: TI-1.5\% ${ }^{\mathrm{a}}$, PA-9.7\% ${ }^{\mathrm{b}}$; UCT: TI$-0.7 \%$, PA- $5.7 \%$ b . Apresentaram também capacidade de diferenciação in vitro nas três linhagens mesodermais e quando analisadas pós criopreservação por citometria de fluxo, todas as amostras apresentaram viabilidade de $80 \%$. Estes resultados indicam que MA e TCU, obtidos tanto no momento de parto como em abatedouro, de fetos bovinos podem ser utilizados como fonte não invasiva e indolor de CTMs e possibilitam a formação de bancos de armazenamento de células.

TERMOS DE INDEXAÇ̃̃O: Vaca holandesa, células tronco mesenquimais, MHC classe II, anexos fetais, imunofenótipo.

\section{INTRODUCTION}

MSC are multipotent cells with high self-renewing capability that can be obtained from a variety of adult tissues and possess immunomodulatory and immunosupressive properties, which increase their use as therapeutic tools. These cells secrete a variety of anti-inflammatory cytokines and growth factors by bioactive molecules, modulating the inflammatory response and the appropriate tissue repair (Nauta \& Fibbe 2007).

The search for new sources of MSC as alternative to bone marrow, which requires an invasive harvesting procedure and exhibits decreased proliferative and differentiation potential associated with donor aging (Pittenger et al. 1999), has increased in the last decades. In this context, fetal annexes emerge as a convenient source for being easily obtained by a non-invasive technique as they are usually discarded after delivery. Besides, they may represent an important resource for the creation of MSC banks in both human (Fauza 2004) and veterinary fields (Cremonesi et al. 2011).

AM has anti-inflammatory, antibiotic and wound protection properties, which combined with the absence or low immunogenicity, led to the clinical use of this tissue as wound dressing for skin burns, lower limb ulcerations and various ophthalmic injuries in humans (Parolini \& Soncini 2011). In veterinary medicine, the AM properties of re-epithelization, fibrosis reduction and angiogenesis modulation have been known at the ophthalmic field for at least a decade (Dua et al. 2004, Solomon et al. 2005) and it is applied mainly in the reconstruction of ocular surface of dogs and horses (Ollivier et al. 2006, Arcelli et al. 2009, Plummer et al. 2009). These characteristics attracted research attention to the use of amnion-derived cells for cell therapy and regenerative medicine in allogeneic and xenogeneic transplantation (Parolini \& Soncini 2011).

In humans, UCT and AM have been proved as sources of MSC with high proliferative rate, in vitro differentiation capacity into at least three mesodermal lineages (osteogenic, adipogenic and chondrogenic), expression of surface markers, such as CD13, CD44, CD90 and CD105, and low expression of MHC II. They also maintain the expression of pluripotency markers like Nanog and OCT-4 without inducing the formation of tumors when applied (Van Pham et al. 2015).

Domestic species, such as swine and company animals, like dogs and cats, provide uncountable opportunities to the development of protocols for veterinary regenerative medicine, which can be implemented as experimental models for humans. Nowadays, there is an extensive number of research and review articles addressing MSC, including fetal annexes-derived MSC, from a variety of domestic animal species (Gonçalves et al. 2014). However, studies using ruminant species are still rare when compared to other species.

Fadel et al. (2011) suggested isolation protocols for obtaining MSC from adipose tissue and umbilical cord blood of sheep and reported difficulties in isolating umbilical cord cells from ovines.

Despite few reports, bovine fetal annexes are remarkable sources of stem cells as they have developmental peculiarities, such as the presence of yolk sac, an important organ for the formation of primordial cells and visible macroscopically until the $55^{\text {th }}$ day of pregnancy. Besides, the high cost to use them as experimental model, especially in studies of assisted reproduction techniques, can be overcome by the existence of pregnant animals, in different gestational ages, at slaughterhouses (Neto et al. 2010).

Recently, Mançanares et al. (2015) demonstrated the presence of MSC in bovine yolk sac obtained from slaughterhouse. These cells expressed the surface markers CD90, CD44 and CD105, were capable to differentiate in vitro toward the mesodermal lineages (osteogenic, chondrogenic and adipogenic) and exhibited expression of pluripotency genes Oct-4, Nanog and Sox-2.

Isolation and differentiation of MSC derived from umbilical cord blood were first reported in 2011 (Raoufi et al. 2011). In the following year, Cardoso et al. (2012) isolated and cultivated bovine Wharton's jelly-derived cells, suggesting UCT as a promising source of MSC for cell therapy and biotechnology. They were also able to cultivate these cells in a three-dimensional (3D) system and without serum addition in the medium. 
Corradetti et al. (2013) described, for the first time, the isolation of bovine MSC derived from AM, using its epithelial layer though, and from amniotic fluid. They reported that MSC from both sources were capable to differentiate in vitro toward ectodermal and mesodermal lineages when properly induced.

With the exception of the study from Mançanares et al. (2015), all reports with bovine fetal annexes mentioned above used samples obtained during eutocic births. In our laboratory, we successfully obtained equine MSC derived from amniotic fluid (De Vita et al. 2013), AM and UCT (De Vita 2011) harvested at slaughterhouses, using fetuses at initial, middle and final term of pregnancy. This had encouraged us to apply the same harvesting procedure to bovine species, considering there is a large number of commercial bovine slaughterhouses.

Adding this fact to the lack of studies with fetal annexes-derived MSC in the bovine species, this study aimed to isolate, characterize, differentiate and cryopreserve MSC derived from the mesenchymal portion of the AM and UCT, obtained from term fetuses during assisted delivery of Holstein cows as well as from fetuses at first trimester of pregnancy harvested in slaughterhouse, in order to provide an economic and easily obtained harvesting technique.

\section{MATERIALS AND METHODS}

All procedures were approved by the Ethics Committee of the College of Veterinary Medicine and Animal Sciences from São Paulo State University “Júlio de Mesquita Filho” (n 30/2013 Botucatu, SP).

Amniotic membrane and umbilical cord harvesting. Samples were isolated from neonates during assisted delivery (AD) of Holstein cows at Fazenda Colorado (Araras, SP) and from fetuses at initial third of pregnancy (IT) obtained at Mondelli slaughterhouse (Bauru, SP). Six samples of each structure, measuring about 10 $\mathrm{cm}^{2}$, were collected for both AD and IT groups. They were maintained in Hank's Balanced Salt Solution (HBSS, Invitrogen, USA) supplemented with $1 \%$ penicillin/streptomycin (Gibco, USA) until later laboratory processing. Transportation was performed at $5 \mathrm{C}$ using the semen cooling system Botuflex ${ }^{\circledR}$ (Botupharma, Brazil).

Isolation and cell culture. All laboratory procedures were performed at the Animal Advanced Assisted Reproduction and Cell Therapy Laboratory (LANÇA) of the School of Veterinary Medicine and Animal Sciences (Unesp-Botucatu, SP). Samples were washed with HBSS (Invitrogen, USA) supplemented with 1\% penicillin/streptomycin (Gibco, USA) and minced to facilitate the enzymatic digestion using $0.1 \%$ collagenase type I solution (Gibco, USA) for 2 hours in water bath at 37C. During this period, samples were agitated by vortex every 15 minutes.

After digestion, samples were filtered through $70 \mu \mathrm{m}$ cell strainer (BD, USA) and centrifuged at $600 \mathrm{G}$ for 10 minutes with culture medium consisting of DMEM low glucose/F12 (1:1, Gibco, USA), supplemented with $20 \%$ fetal bovine serum (SFB, Gibco, USA), $1 \%$ penicillin/streptomycin (Gibco, USA) and 1.1\% amphotericin B (Gibco, USA). Pellet was resuspended in culture medium and incubated in $25 \mathrm{~cm}^{2}$ plastic flasks (Sarstedt, USA) at $37.5^{\circ} \mathrm{C}$ in a humidified atmosphere containing $5 \% \mathrm{CO}_{2}$. Culture medium was changed every 48 hours until $80 \%$ confluence was reached, when adherent cells were detached with trypsin and passaged to subcultures.

Immunocytochemistry. Cells from third passage (P3) were transferred to 24-wells plates (Sarstedt, USA). After reaching 80\% confluence, cells were fixed and permeabilized with Cytofix/Cytoperm $^{\mathrm{TM}}$ (BD, USA), followed by blocking of endogenous peroxidase for
20 minutes. Then, samples were incubated for one hour in 3\% milk powder solution to block nonspecific proteins. Primary antibodies mouse anti-horse MHC class II monomorphic (clone CVS20, ABD Serotec, United Kingdom), Rb pAb to NANOG (ABCAM, USA), polyclonal goat anti Oct-4 (1:100, SCR002, MILIPORE, USA) and negative control IgG anti mouse (Dako Cytomation, Denmark) were incubated for 18 hours at $4^{\circ} \mathrm{C}$, protected from light. Staining was carried out by using chromogenic substrate DAB solution (Dako Cytomation, Denmark) for 5 minutes, followed by Harris Hematoxylin (Merck, Brazil) counter-coloration for 1 minute. The reaction was examined under an inverted light microscope (Leica Microsystems, Germany).

Flow cytometry. MSC at P3 from the distinct groups were analyzed by flow cytometer FACS Calibur (BD, USA). Cells were incubated with primary antibodies mouse anti CD44 (clone BAG40A, 1:100, VMRD, USA) mouse anti MHCII FITC (clone CVS20, 1:100, ABD Serotec, United Kingdom) e mouse anti CD34 (clone 581, 1:50, BD, USA). For CD44 marker, the secondary marker goat anti-mouse IgG- FITC (clone STAR117F, 1:200, ABD Serotec, United Kingdom) was used. Reactions were performed in accordance with the manufacturer's protocol of each antibody. Expression was based in cross-reaction.

Osteogenic and Adipogenic differentiation. For the differentiation assays, MSC at P3 were cultured in 6-wells plates (Sarstedt, USA) until $60 \%$ confluence was reached. At this point, culture medium was replaced by the respective differentiation media (StemPro, Gibco, USA). Culture was maintain for 10 days with the medium being changed every 48 hours. After this period, the cell monolayer were fixed with paraformaldehyde $4 \%$ for 30 minutes and submitted to histological staining. Osteogenic differentiation was confirmed by the visualization of calcium matrix deposits stained with Alizarin Red S (2\% solution e pH 4.2, Sigma-Aldrich, USA). For the evaluation of adipogenic differentiation, monolayers were stained with Oil red (Sigma-Aldrich, USA) and assessed to the presence of intracytoplasmic lipid droplets.

Chondrogenic differentiation. Chondrogenic differentiation was performed in a 3D system for 21 days. Cells were trypsinised and centrifuged to pellet formation, which was incubated in $15 \mathrm{ml}$ falcon tubes (Corning, USA), containing culture medium, for 24-48 hours. Then, culture medium was replaced by chondrogenic differentiation medium (StemPro Chondrogenesis Kit, Gibco, USA). After 21 days, pellets were fixed in $10 \%$ buffered formalin followed by paraffin embedding and section cutting. Samples were stained with Hematoxylin-Eosin (HE), Alcian Blue $(\mathrm{pH}=2.5)$ and Toluidine Blue $(\mathrm{pH}=1)$ for the visualization of proteoglycan deposits.

Cryopreservation. After P3, MSC from AD and IT groups from both sources were trypsinised and the pellet was resuspended into $1.5 \mathrm{ml}$ cryotubes containing freezing medium (90\% FBS supplemented with $10 \%$ DMSO). Cryotubes were stored in a controlled cooling container (Mr. Frosty, Nalgene, USA) in $-80^{\circ} \mathrm{C}$ freezer for 24 hours and then transferred to liquid nitrogen container at $-196^{\circ} \mathrm{C}$. After 3 to 6 months, samples were thawed and cell viability was analyzed by trypan blue staining method and annexine $\mathrm{V}$ expression by flow cytometry.

Statistical analysis. Data from CD44, CD34 and MHC II markers were expressed as mean and standard error and were submitted to T student test, using PROC GLM from SAS (SAS, Inst. Inc., Cary, NC, USA), to verify if there was significant difference between means and if the factors influenced any dependent variable. All analysis adopted significance level of $\mathrm{P}<0.05$.

\section{Morphology}

\section{RESULTS}

After isolation and initial culture, cells derived from amniotic membrane and umbilical cord tissue were attached to the plastic surface and showed spindle-shaped fibro- 
blastic morphology within 24 hours and, in 48-72 hours, these cells reached $80-90 \%$ confluence. There were no differences in terms of time to adhesion and fibroblastoid morphology between Ad and IT groups from both sources (AM and UCT, Figure 1 and 2 respectively).

\section{Immunophenotype characterization}

Immunocytochemistry for CD44, Oct-4, NANOG and MHC II markers. Qualitative evaluation by immunocytochemistry showed positive staining for CD44 (which is frequently expressed in mesenchymal cells) and Oct-4 and NANOG (which are expressed in embryonic cells and are associated to pluripotent differentiation capacity) in samples from amniotic membrane as well as umbilical cord from both $\mathrm{AD}$ and IT groups. Furthermore, both groups of the different sources lacked MHC II staining, which can be observed in Figure 3 and 4.

Flow cytometry for CD34, CD44 and MHCII. Samples from bovine AM and UCT obtained in slaughterhouse and during assisted delivery were evaluated after P3. Lack of expression was set when results were $\leq 2 \%$.

Cell samples from AM obtained in IT and AD expressed CD44 with no significant difference between the studied groups $(\mathrm{P}>0,05)$. Samples from IT showed lacked expression of CD34 and MHC II markers. On the other hand, the expression of CD34 and MHC II markers from cells obtained during $\mathrm{AD}$, although low, was significantly higher in comparison with the values obtained in the IT group sam-

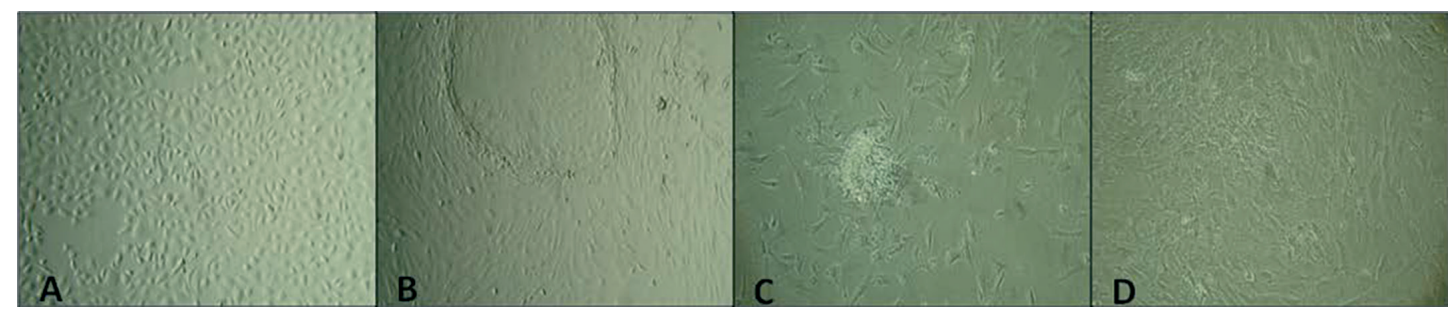

Fig.1. (A) AM samples harvested at initial third of pregnancy showing fibroblastoid morphology at 24h; (B) AM-derived cells from IT group showing 90\% confluence in 48h; (C) AM samples harvested during assisted delivery showing fibroblastoid morphology in 48h; (D) AM-derived cells obtained during assisted delivery showing 90\% confluence at 4 days. Magnification 10x.

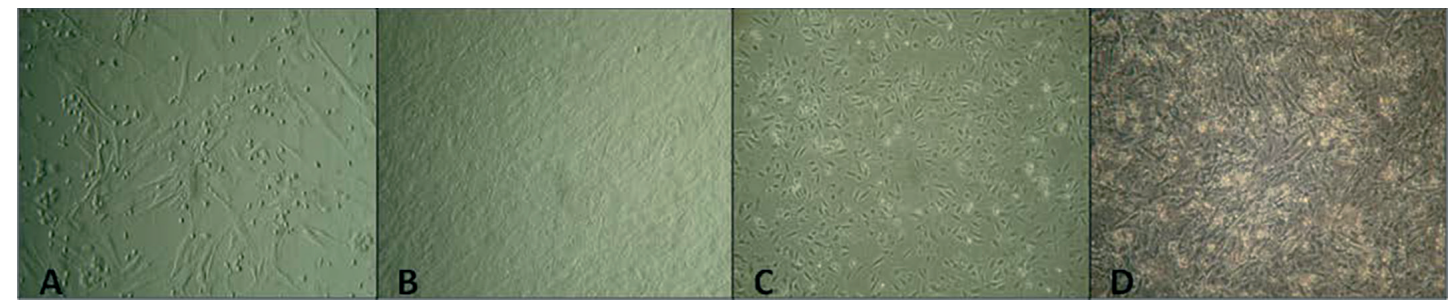

Fig.2. (A) UCT samples harvested at initial third of pregnancy showing fibroblastoid morphology at 24h; (B) AM-derived cells from IT group showing 90\% confluence in 48h; (C) AM samples harvested during assisted delivery showing fibroblastoid morphology in 48h; (D) AM-derived cells obtained during assisted delivery showing 90\% confluence at 4 days. Magnification 10x.

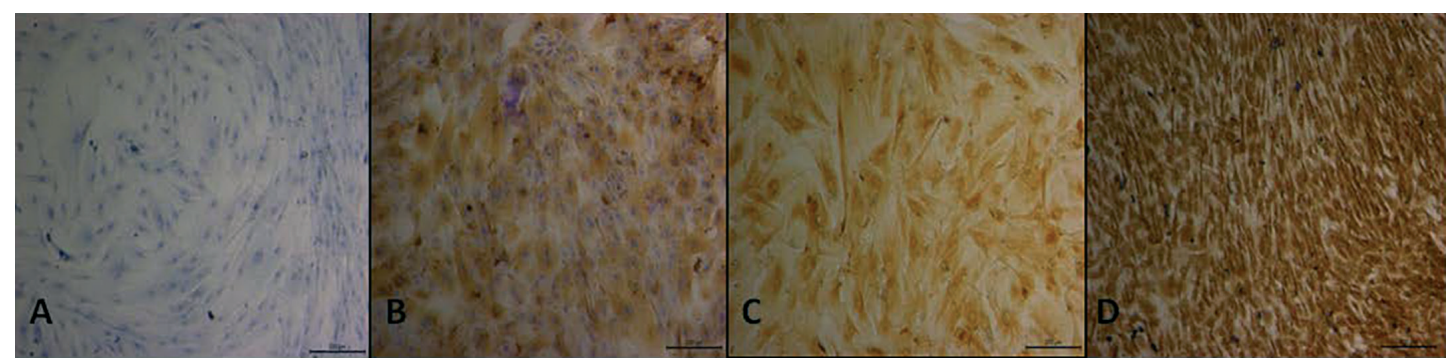

Fig.3. Immunocytochemistry of AM-derived cells from bovine gestational uterus at early pregnancy harvested at slaughterhouse (A) MHC II (negative staining); (B) Oct-4 (positive staining); (C) NANOG (positive staining); (D) CD44 (positive staining). Magnification 10x.

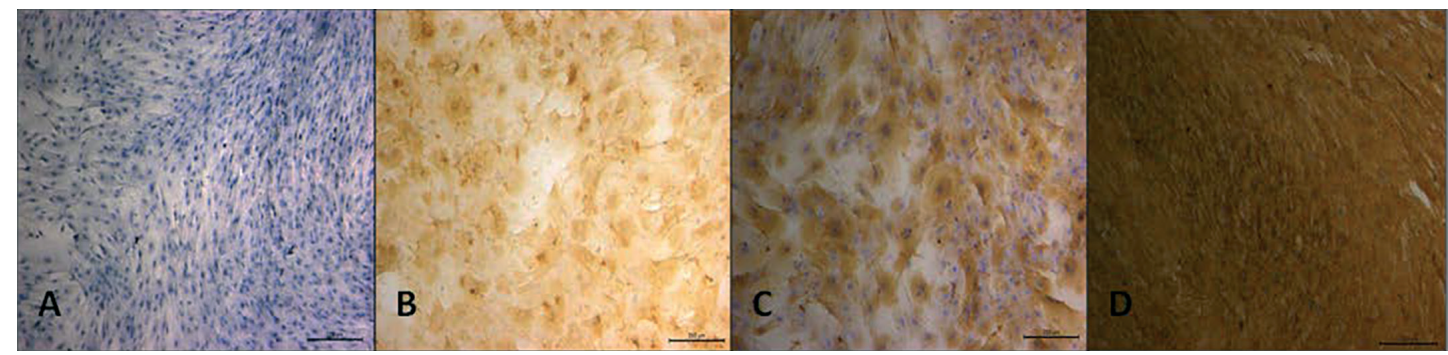

Fig.4. Immunocytochemistry of UCT-derived cells from bovine gestational uterus at early pregnancy harvested at slaughterhouse (A) MHC II (negative staining); (B) Oct-4 (positive staining); (C) NANOG (positive staining); (D) CD44 (positive staining). Magnification 10x. 
Table 1. Mean values and standard error of the expression of CD44, CD 34 and MHC class II markers of MSC derived from bovine $A M$, harvested from gestational uterus at initial third of pregnancy and from fetuses during assisted delivery of Holstein cows

\begin{tabular}{ccc}
\hline Markers & \multicolumn{2}{c}{ Expression of the markers (\%) } \\
\cline { 2 - 3 } & Initial third & Moment of delivery \\
\hline CD44 & 56.8 & 59.5 \\
CD34 & $0.3 \mathrm{a}$ & $3.4 \mathrm{~b}$ \\
MHCII & $1.05 \mathrm{a}$ & $9.7 \mathrm{~b}$
\end{tabular}

ples $(\mathrm{P}<0.05)$. Nonetheless, the expression level did not exceed $10 \%$ in any sample (Table 1 ).

UCT-derived cells of the different groups showed expression for CD44 and non expression for CD34. There was no difference in the expression of CD44 and CD34 between the studied groups. However, MHC II expression was significantly higher in AD group than IT group $(\mathrm{P}<0.05)$ (Table 2$)$.
Table 2. Mean values and standard error of the expression of CD44, CD 34 and MHC class II markers of MSC derived from bovine UCT, harvested from gestational uterus at initial third of pregnancy and from fetuses during assisted delivery of Holstein cows

\begin{tabular}{ccc}
\hline Markers & \multicolumn{2}{c}{ Expression of the markers (\%) } \\
\cline { 2 - 3 } & Initial third & Moment of delivrery \\
\hline CD44 & 7.6 & 63.4 \\
CD34 & 0.4 & 1.4 \\
MHCII & $0.7 \mathrm{a}$ & $5.2 \mathrm{~b}$
\end{tabular}

Tri-lineage differentiation: osteogenic, adipogenic and condrogenic

AM osteogenic differentiation. All samples from AM of both studied groups showed morphological changes and presence of calcium-rich extracellular matrix (Fig.5).

AM adipogenic differentiation. When assessed to adipogenic differentiation, all AM samples from both groups

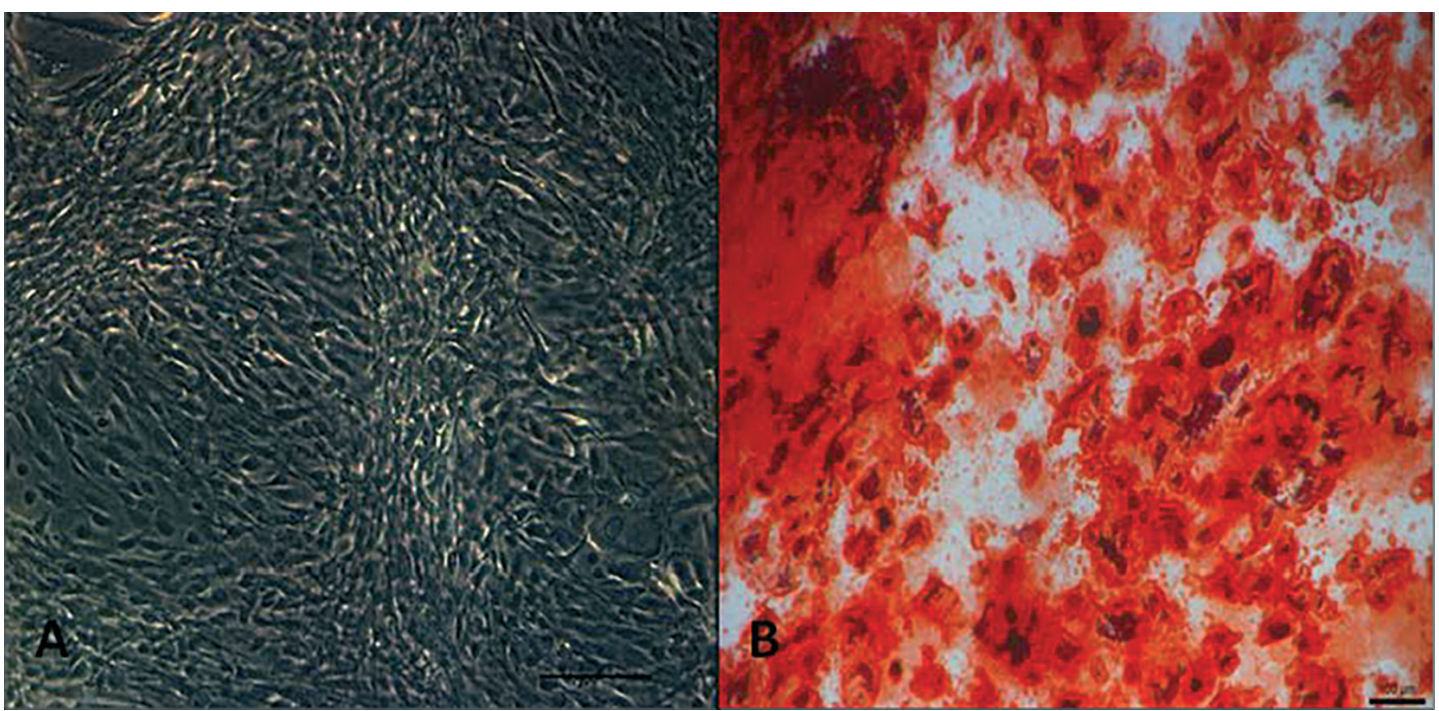

Fig.5. Osteogenic differentiation of AM-derived MSC harvested from bovine gestational uterus at early pregnancy obtained in slaughterhouse and from fetuses during assisted delivery of Holstein cows. (A) Negative control for osteogenic differentiation; (B) osteogenic differentiation displaying extra cellular calcium deposits stained with Alizarin Red. Magnification 10x.

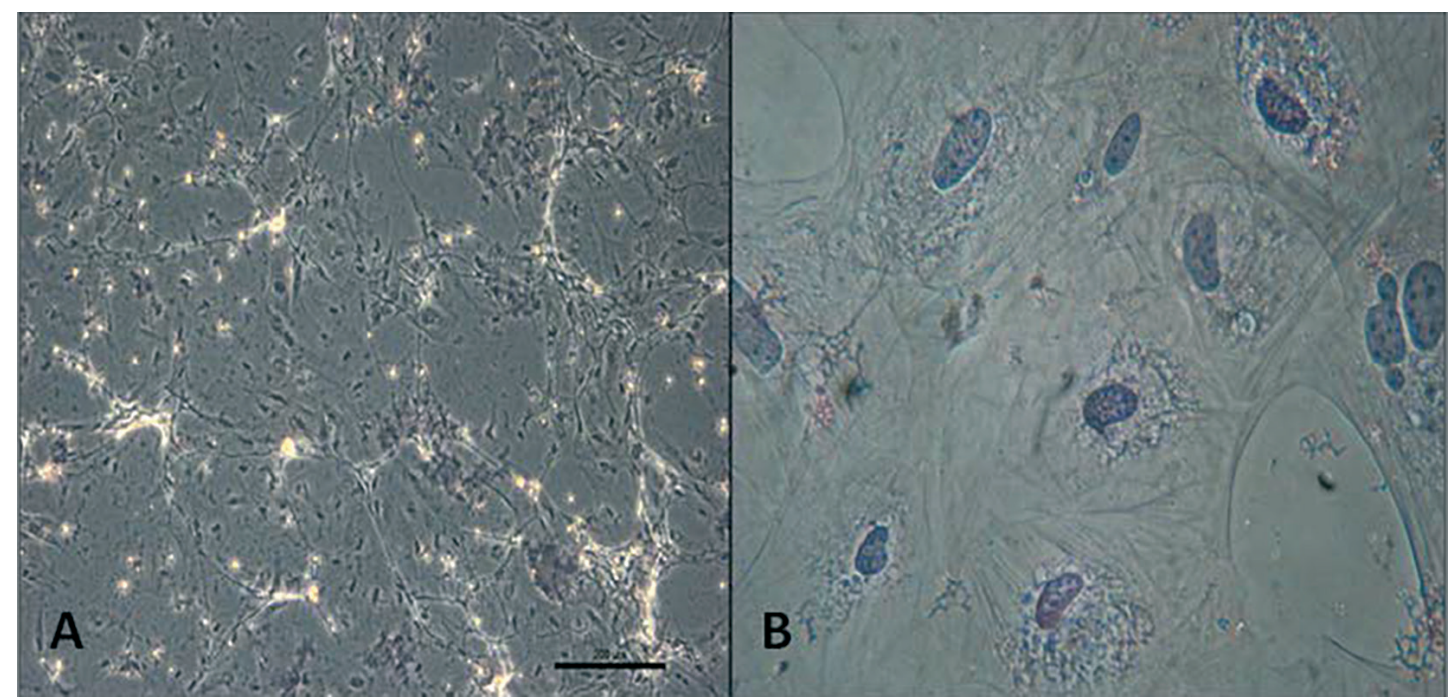

Fig.6. Adipogenic differentiation of AM-derived MSC harvested from bovine gestational uterus at early pregnancy obtained in slaughterhouse and from fetuses during assisted delivery of Holstein cows. (A) Negative control for adipogenic differentiation; (B) adipogenic differentiation displaying lipid droplets stained with Oil Red and morphological changes. Magnification 20x. 
showed morphological changes and presence of lipid droplets in the cytoplasm (Fig.6).

AM chondrogenic differentiation. Evaluation of the chondrogenic differentiation of MA samples from both groups was made by histological analysis of the 3D cultures. Samples showed morphological changes and presence of proteoglycans deposits (Fig.7).

UC osteogenic differentiation. In the evaluation of os-

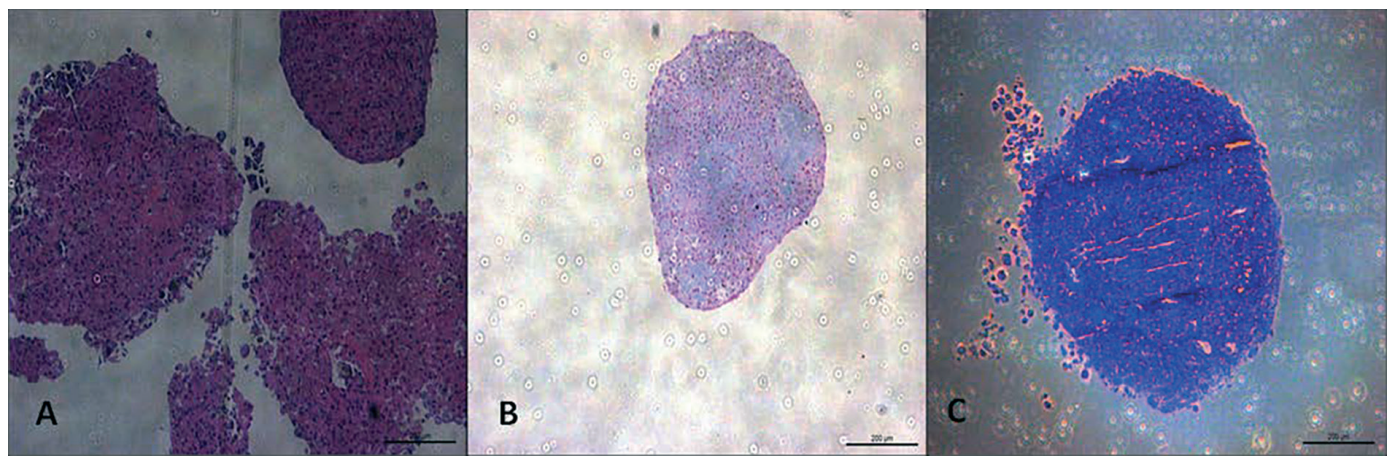

Fig.7. Chondrogenic differentiation of AM-derived MSC harvested from bovine gestational uterus at early pregnancy obtained in slaughterhouse and from fetuses during assisted delivery of Holstein cows. (A) Morphological changes observed by the red HE staining; (B) presence of glycosaminoglycan stained in blue by Alcian blue dye; (C) metacromasia visualized by toluidine blue staining. Magnification 10x.

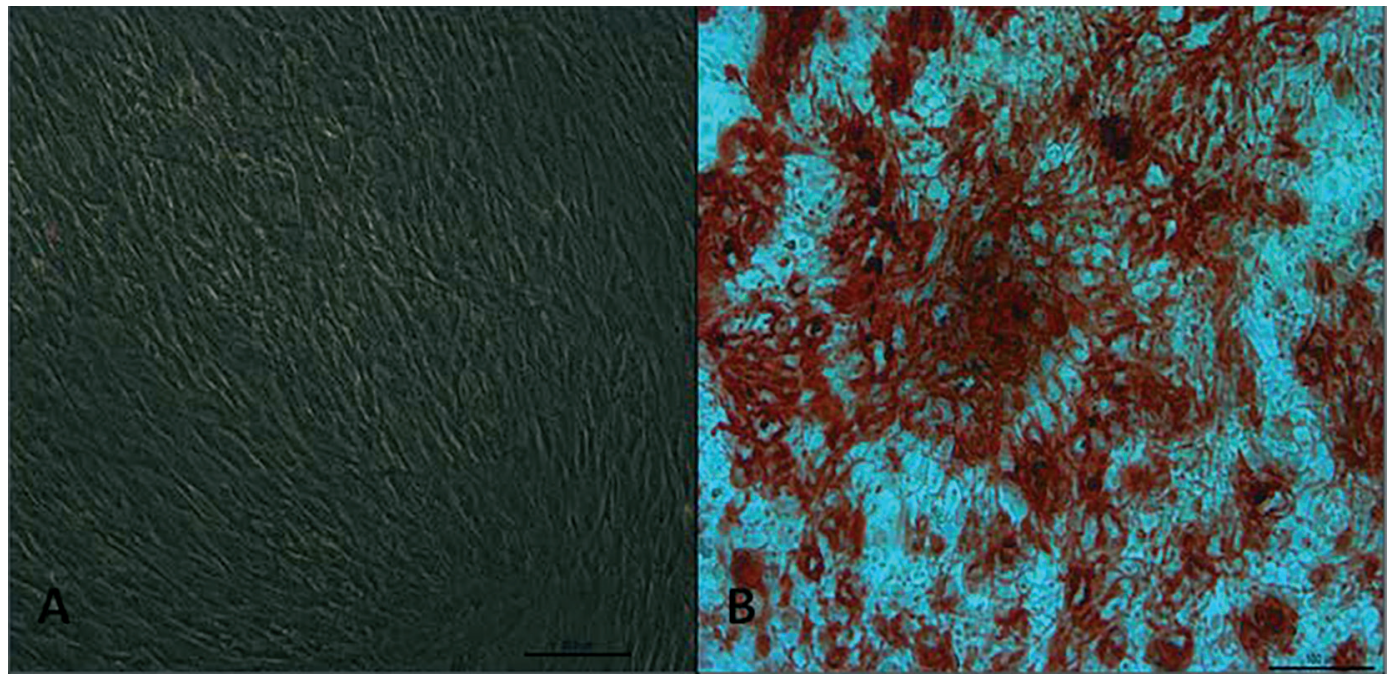

Fig.8. Osteogenic differentiation of UCT-derived MSC harvested from bovine gestational uterus at early pregnancy obtained in slaughterhouse and from fetuses during assisted delivery of Holstein cows. (A) Negative control for osteogenic differentiation; (B) osteogenic differentiation displaying extra cellular calcium deposits stained with Alizarin Red. Magnification 10x.

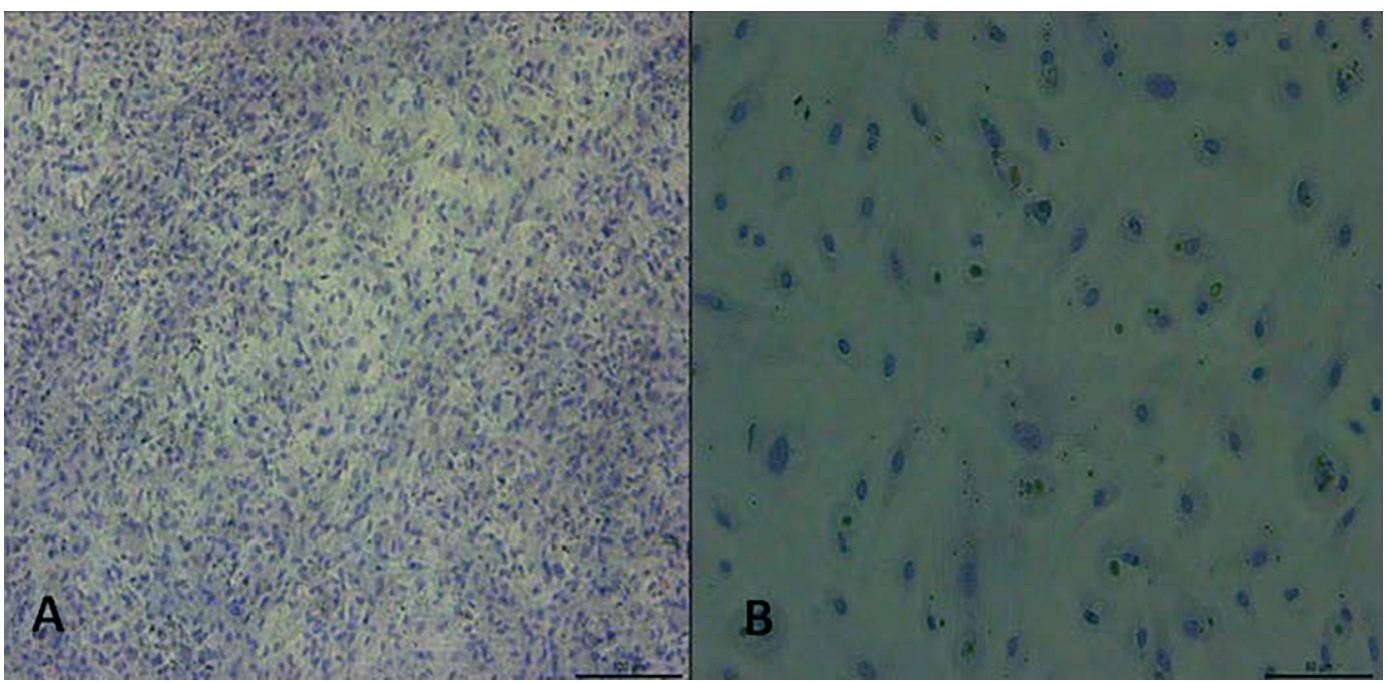

Fig.9. Adipogenic differentiation of UCT-derived MSC harvested from bovine gestational uterus at early pregnancy obtained in slaughterhouse and from fetuses during assisted delivery of Holstein cows. (A) Negative control for adipogenic differentiation; (B) adipogenic differentiation displaying lipid droplets stained with Oil Red and morphological changes. Magnification 10x. 


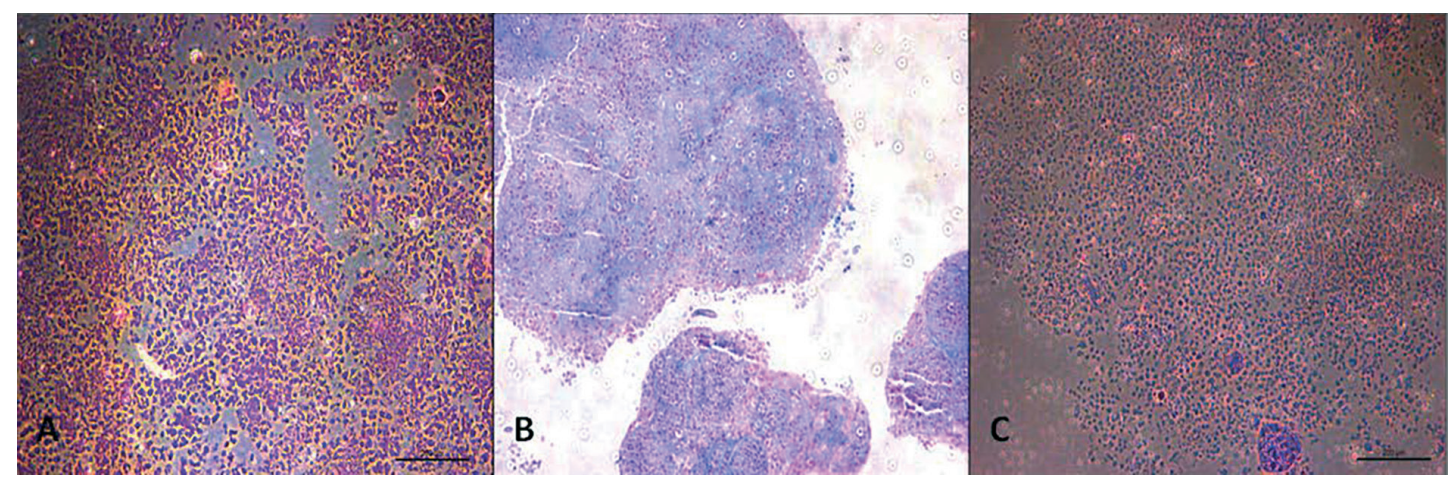

Fig.10. Chondrogenic differentiation of UCT-derived MSC harvested from bovine gestational uterus at early pregnancy obtained in slaughterhouse and from fetuses during assisted delivery of Holstein cows. (A) Morphological changes observed by the red HE staining; (B) presence of glycosaminoglycan stained in blue by Alcian blue dye; (C) metacromasia visualized by toluidine blue staining. Magnification 10x.

teogenic differentiation of UCT samples from the distinct groups, we observed morphological changes and presence of calcium-rich extracellular matrix (Fig.8).

UC adipogenic differentiation. When evaluated to adipogenic differentiation, all UCT samples from AD and IT groups showed morphological changes and presence of lipid droplets in the cytoplasm (Fig.9).

UC chondrogenic differentiation. Evaluation of the chondrogenic differentiation of UCT samples from both groups was made by histological analysis of the 3D cultures. All samples showed morphological changes and presence of proteoglycans deposits (Fig.10).

\section{Viability, apoptosis and necrosis assays}

MSC from all samples of both groups were cryopreserved after P3 and thawed subsequently for viability, apoptosis and necrosis assays. All AM samples (IT and AD) showed $80 \%$ of viability (Fig.11). We observed the same results for UCT samples obtained at IT and during AD (Fig.12).

\section{DISCUSSION}

The search of new sources of MSC as alternative to bone marrow and adipose tissue has increased in the last decade, especially in human field. In this respect, fetal annexes have arisen in the last 10 years as a convenient source for being easily and non-invasively obtained from tissues that are usually discarded and for being an important candidate to be used as resource for the creation of cell banks for both human (Fauza 2004, Gucciardo 2009, Parolini \& Soncini 2011) and veterinary fields (Cremonesi et al. 2011). These cells also stand out for their secretion of a variety of anti-inflammatory cytokines and growth factors through bioactive molecules, which modulate the inflammatory response and the appropriate tissue repair (Parolini et al. 2008).

Studies with bovine MSC obtained from fetal annexes, until now, are little described in literature (Raoufi et al. 2011, Cardoso et al. 2012, Corradetti et al. 2013, Mançanares et al. 2015). Therefore, the aim of the present study was to isolate, characterize, differentiate and cryopreserve bovine MSC obtained from the amniotic mesenchymal layer, for the first time, and the extravascular matrix of umbilical cord, which were harvested from neonates during assisted
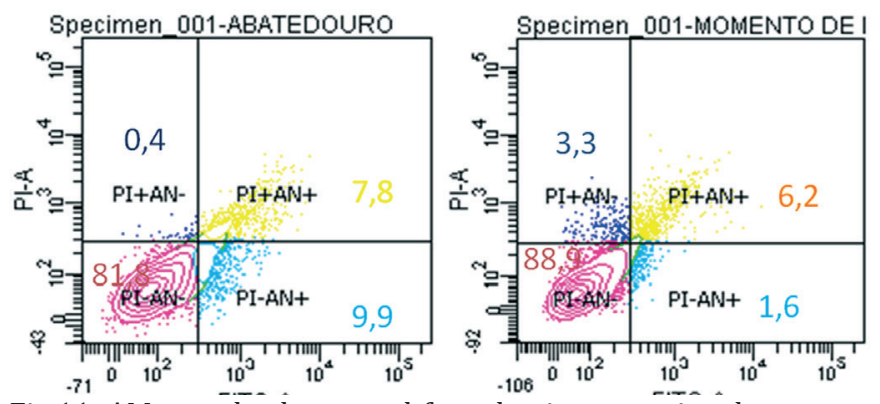

Fig.11. AM samples harvested from bovine gestational uterus at early pregnancy obtained in slaughterhouse and from fetuses during assisted delivery of Holstein cows showing 80\% cell viability after being cryopreserved.
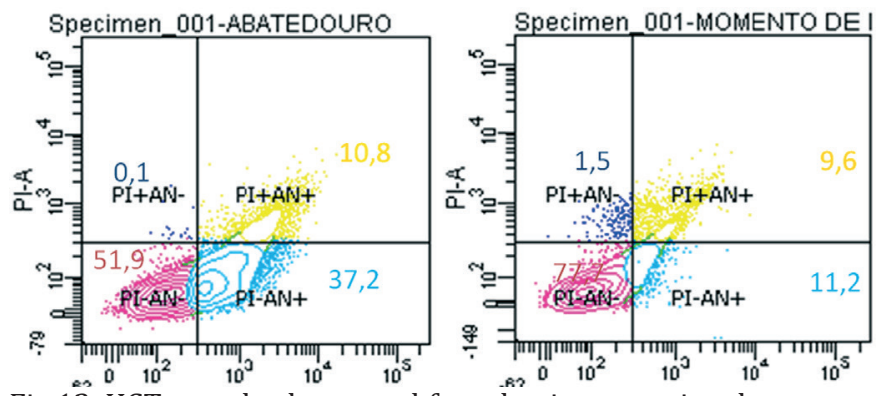

Fig.12. UCT samples harvested from bovine gestational uterus at early pregnancy obtained in slaughterhouse and from fetuses during assisted delivery of Holstein cows showing $80 \%$ cell viability after being cryopreserved.

delivery of Holstein cows and from fetuses at initial third of pregnancy obtained in slaughterhouse.

All cultured samples showed plastic adherence and fibroblastoid morphology within 24 hours and reached $80 \%$ confluence in 48-72 hours of culture, which is in agreement with results from studies with human (Zhang \& Fan, 2010), canine (Lee et al. 2012), equine (Koch et al. 2007, Lange-Consiglio et al. 2012, De Vita et al. 2013) and bovine (Raoufi et al. 2011, Cardoso et al. 2012, Mançanares et al. 2015) MSC.

During primary culture, few samples displayed circumscribed cell formations with polygonal morphology, which were described as cells from the aminiotic epithelial portion in humans by Miki et al. (2005) and in bovine by Corradetti et al. (2013). As reported by De Vita et al. (2013), the 
presence of these epithelial cells decreased through passages until P3 when it could not be observed.

Cells submitted to immunocytochemistry stained for CD44, which confirms their mesenchymal origin, and for Oct-4 and NANOG, which are pluripotency markers that can also be expressed in adult stem cells with multipotent characteristics, including MSC; and lacked MHC II staining. This data supports the findings already reported in several studies with MSC derived from fetal annexes in different species (Uranio et al. 2011, Lee et al. 2012, Calloni et al. 2014, Gonçalves et al. 2014).

The lack of MHC II expression results in lower risks of immune response to allogeneic therapy. Several studies reported no expression of MHC II in MSC by the techniques of flow cytometry (Hoynowski et al. 2007, Carrade et al. 2012) and RT-PCR (Lovati et al. 2011, Corradetti et al. 2013). In the present study, however, we have observed lack of MHC II expression only when analyzing by immunocytochemistry.

In the immunophenotypical analysis by flow cytometry, all samples highly expressed CD44 marker and did not or minimally expressed CD34 marker (AM from AD group, $3.4 \%)$. CD34 is a common marker for hematopoietic cells. Gonçalves et al. (2014) described MSC as a highly heterogeneous cell population that includes, in some cases, CD34 positive cells.

As described before, AM and UCT-derived cells showed negative immunocytochemistry staining for MHC II; however, when evaluated quantitatively by flow cytometry, the cells obtained during AD low expressed MHC II (AM: 9.7\% and UCT: $5.2 \%$, respectively) and significantly differed from AM and UCT samples of IT group $1.05 \%$ and $0.7 \%$ respectively). Similar results were obtained in study with equine umbilical cord blood-derived MSC, which also observed a low expression, but not absent, of MHC II (De Schauwer et al. 2014); and in a study with equine UCT-derived MSC that reported 5.6\% expression of MHC-II (Barberini et al. 2014).

The hypo-immunogenic profile of MSC is associated to the absence of MHC II expression, making it an important factor to the application of MSC as immunomodulators and allowing the allogeneic transplantation of these cells (Koppula et al. 2009). In this study, the results obtained suggest that the first trimester of pregnancy is the eligible moment to harvest MSC that possess a more appropriate and safe immunological phenotype for clinical use. Still, it is important to highlight that this classification (negative or positive) vary between authors (Dominici et al. 2006, Seo et al. 2012, Yuan et al. 2013). Besides, the harvest at slaughterhouse showed more accessible and free from environmental contamination in comparison to the harvest at field. At delivery moment, if the fetal membranes are in contact with the stall bedding before they are harvested; this material must not be used due to high microbial contamination.

For the in vitro differentiation, one of the most important properties in MSC characterization is the ability of these cells to differentiate into at least three tissues from the mesodermal lineage. All samples showed osteogenic, adipogenic and chondrogenic differentiation capacity when exposed to the respective inductor media. This data is in accordance with results obtained in other studies with cells derived from bovine fetal annexes (Raoufi et al. 2011, Cardoso et al. 2012, Corradetti et al. 2013, Gonçalves et al. 2014).

An important aspect of cell therapy is the formation of cell banks that allows greater resource availability for the treatment of diseases. Therefore, it is necessary to utilize safe protocols that allow cells to maintain their viability for a long period. In pioneer study, Liu et al. (2011) obtained positive results for in vitro expansion and differentiation after submitting umbilical cord blood-derived MSC to long-term cryopreservation. In the present study, after thawing, MSC from both assessed tissues showed cell viability higher than $80 \%$ when stained with propidium iodate and annexine $\mathrm{V}$ and analyzed by flow citometry.

Furthermore, the transportation at $5 \mathrm{C}$ for 48 hours did not interfere on the isolation and following MSC development, which allows even more the use of these cells at the clinical application.

\section{CONCLUSIONS}

Based on the proposed aims, we can conclude that MSC may be easily isolated from the AM as well as the UCT from bovine fetuses obtained in slaughterhouse or during assisted delivery. The transport at $5 \mathrm{C}$ for 48 hours also showed viable to send samples to the laboratory.

Immunocytochemistry analysis demonstrated that MSC from the evaluated tissues show typical characteristics of stromal cells, but also signs of pluripotency, which suggests a high therapeutic potential.

The low expression of MHC II indicates a low immunogenic characteristic that is desirable in cells intended to cell therapy. Cells from both the amniotic mesenchymal layer and the UCT showed a satisfactory differentiation potential into mesodermal tissues, which confirms their characterization as MSC.

Cell viability was preserved with the use of DMSO as cryoprotector and the employment of controlled freezing and thawing curves, which indicates the possibility of storing these cells in cell banks.

Our results suggest that the amniotic mesenchymal layer and the UCT harvested in fetuses at initial third of pregnancy and during assisted delivery are excellent sources of MSC for veterinary medicine of bovine species, with potential use of them as an experimental model, that maintain their morphological characteristics after cryopreservation. However, more studies related to the identification of mechanisms and molecules that participate in the biological functions and that control the survival and proliferation of these cells after in vivo application are required.

Acknowledgment.- The authors would like to acknowledge CAPES and FUNVET for the financial support.

\section{REFERENCES}

Arcelli R., Tibaldini P., Angeli G. \& Bellezza E. 2009. Equine amniotic membrane transplantation in some ocular surface diseases in the dog and cat: a preliminary study. Vet. Res. Commun. 33(1):169-171.

Barberini D.J., Freitas N.P.P., Magnini M.S., Maia L., Listoni A.J., Heckler M.C., Sudano M.J., Golim M.A., Landim-Alvarenga F.C. \& Amorim R.M. 2014. Equine mesenchymal stem cells from bone marrow, adipose tissue and umbilical cord: immunophenotypic characterization and differentia- 
tion potential. Stem Cell Res. Ther. 5:25. <http://stemcellres.com/content/5/1/25>

Calloni R., Viegas G.S., Turck P., Bonatto D. \& Henriques J.A.P. 2014. Mesenchymal stromal cells from unconventional model organisms. Cytotherapy 16:3-16.

Cardoso T.C., Ferrari H.F., Garcia A.F., Novais J.B., Frade C.S., Ferrarezi M.C., Andrade A.L. \& Gameiro R. 2012. Isolation and characterization of Wharton's jelly-derived multipotent mesenchymal stromal cells obtained from bovine umbilical cord and maintained in a defined serumfree three-dimensional system. BMC Biotechnol. 12:18.

Carrade D.D. \& Borjesson D.L. 2013. Immunomodulation by mesenchymal stem cells in veterinary species. Comp. Med. 63(3):207-217.

Corradetti B., Meucci A., Bizzaro D., Cremonesi F. \& Lange-Consiglio A. 2013. Mesenchymal stem cells from amnion and amniotic fluid in the bovine. Reproduction 145:391-400.

Cremonesi F., Corradetti B. \& Lange C.A. 2011. Fetal adnexa derived stem cells from domestic animals: progress and perpectives. Theriogenology 75:1400-1415.

De Schauwer C., Goossens K., Piepers S., Hoogewijs M.K., Govaere J.L.J., Smits K., Meyer E., Van Soom A. \& Van de Walle G.R. 2014. Characterization and profiling of immunomodulatory genes of equine mesenchymal stromal cells from non-invasive sources. Stem Cell Res. Ther. 5(1):6.

De Vita B. 2011. Isolamento e caracterização de células-tronco mesenquimais derivadas de anexos fetais equinos. Tese de Doutorado em Medicina Veterinária, Faculdade de Medicina Veterinária e Zootecnia, Universidade Estadual Paulista, Botucatu, SP. 74p.

De Vita B., Campos L.L., Listoni A.J., Maia L., Sudano M.J., Curcio B.R., Landim-Alvarenga F.C. \& Prestes N.C. 2013. Isolation, culture and differentiation of mesenchymal stem cells derived from equine amniotic fluid obtained from different gestational ages. Pesq. Vet. Bras. 33(4):535-542.

Dominici M., Le Blanc K., Mueller I., Slaper-Cortenbach L., Marini F.C., Krause D.S., Deans R.J., Keating A., Porkcop D.J. \& Howitz E.M. 2006. Minimal criteria for defining multipotent mesenchymal stroma cells. The International Society for Cellular Therapy Position Statement. Cytotherapy 8:315-317.

Dua H.S., Gomes J.A., King A.J. \& Maharajan V.S. 2004 The amniotic membrane in ophthalmology. Surv. Ophthalmol. 49:51-77.

Fadel L., Viana B.R., Feitosa M.L., Ercolin A.C., Roballo K.C., Casals J.B., Pieri N.C., Meirelles F.V., Martins D.S., Miglino M.A. \& Ambrósio C.E. 2011. Protocols for obtainment and isolation of two mesenchymal stem cell sources in sheep. Acta Cir. Bras. 26(4):267-273.

Fauza D. 2008. Amniotic fluid stem cells. Best Pratc. Res. Clin. Obstet. Gynaecol. 18:877-891.

Gonçalves N.N., Ambrósio C.E. \& Piedrahita J.A. 2014. Stem cells and regenerative medicine in domestic and companion animals: a multispecies perspective. Reprod. Domest. Anim. 49(2):10. (Review)

Gucciardo L., Lories R., Ochsenbein-Kolble N., Done E., Zwijsen A. \& Deprest J. 2009. Fetal mesenchymal stem cells: isolation, properties and potential use in perinatology and regenerative medicine. BJOG 116:166-172.

Hoynowski S.M.. Fry M.M., Gardner B.M., Leming M.T., Tucker J.R., Black L., Sand T. \& Mitchell K.E. 2007. Characterization and differentiation of equine umbilical cord-derived matrix cells. Biochem. Biophys. Res. Commun. 362:347353.

Koch T.G., Heerkens T., Thomsen P.D. \& Betts D.H. Isolation of mesenchymal stem cells from equine umbilical cord blood. BMC Biotechnol. 7:26.

Koppula P.R., Chelluri L.K., Polisetti N. \& Vemuganti G.K. 2009. Histocompatibility testing of cultivated human bone marrow stromal cells: a promising step towards pre-clinical screening for allogeneic stem cell therapy. Cellular Immunol. 259:61-65.

Lange-Consiglio A., Corradetti B., Bizzaro D., Magatti M., Ressel L., Tassan S., Parolini 0. \& Cremonesi F. 2012. Characterization and potential applications of progenitor-like cells isolated from horse amniotic membrane. J. Tissue Eng. Reg. Med. 6:622-635.

Lee K.S., Nah J.J., Lee B.C., Lee H.T., So B.J. \& Cha S.H. 2013. Maintenance and characterization of multipotent mesechymal stem cells from the amniotic membrane. Res. Vet. Sci. 94:144-151.

Liu G., Ye X., Zhu Y., LiI Y., Sun J., Cui L. \& Ca Y. 2011. Osteogenic differentiation of
GFP-labeled human umbilical cord blood derived mesenchymal stem cells after cryopreservation. Cryobiology, doi: 10.1016/j.cryobiol.2011.05.005

Lovati A.B., Corradetti B., Lange Consiglio A., Recordati C., Bonacina E., Bizzaro D. \& Cremonesi F. 2011 Comparison of equine bone marrow-, umbilical cord matrix and amniotic fluid-derived progenitor cells. Vet. Res. Comm. 35:103-121.

Mançanares C.A., Oliveira V.C., Oliveira L.J., Carvalho A.F., Sampaio R.V., Mançanares A.C., Souza A.F., Perecin F., Meirelles F.V., Miglino M.A. \& Ambrósio C.E. 2015. Isolation and characterization of mesenchymal stem cells from the yolk sacs of bovine embryos. Theriogenology 84(6):887-898.

Miki T., Lehmann T., Cai H., Stolz D.B. \& Strom S.C. 2005. Stem cell characteristics of amniotic epithelial cells. Stem Cells 23:1549-1559.

Nauta A.J. \& Fibbe W.E. 2007. Immunomodulatory properties of mesenchymal of bone marrow. Analysis of precursor cells for osteogenic and hematopoietic tissues. Transplantation 6:230-247.

Neto A.C.A., Pereira F.T.V., Santos T.C., Ambrosio C.E., Leiser R. \& Miglino M.A. 2010. Morphophysical recording of bovine conceptus (Bos indicus) and placenta from day 20 to 70 of pregnancy. Reprod. Dom. Anim. 45:760-772.

Ollivier F.J., Kallberg M.E., Plummer C.E., Barrie K.P., O’Reilly S., Taylor D.P., Gelatt K.N. \& Brooks D.E. 2006. Amniotic membrane transplantation for corneal surface reconstruction after excision of corneolimbal squamous cell carcinomas in nine horses. Vet. Ophthalmol. 9:404-413.

Parolini O., Alviano F., Bagnara G.P., Bilic G., Bühring H.J., Evangelista M., Hennerbichler S., Liu B., Magatti M., Mao N., Miki T., Marongiu F., Nakajima H., Nikaido T., Portmann-Lanz C.B., Sankar V., Soncini M., Stadler G., Surbek D., Takahashi T.A., Redl H., Sakuragawa N., Wolbank S., Zeisberger S., Zisch A. \& Strom S.C. 2008. Concise review: isolation and characterization of cells from human term placenta: outcome of the first international Workshop on Placenta Derived Stem Cells. Stem Cells 26:300-311.

Parolini O. \& Soncini M. 2011. Placenta as a Source of Stem Cells and as a Key Organ for Fetomaternal Tolerance, p.11-23. In: Bhattacharya N. \& Stubblefield P. (Eds), Regenerative Medicine Using Pregnancy-Specific Biological Substances. Springer-Verlag, London. DOI: 10.1007/978-1-84882-718-9_2

Pittenger M.F., Mackay A.M., Beck S.C., Jaiswal R.K., Douglas R., Mosca J.D., Moorman M.A., Simonetti D.W., Craig S. \& Marshak D.R. 1999. Multilineage potential of adult human mesenchymal stem cells. Science 284:143-147.

Plummer C.E., Ollivier F., Kallberg M., Brooks D., Barrie K., Utter M. \& Gelatt K. 2009. The use of amniotic membrane transplantation for ocular surface reconstruction: a review and series of 58 equine clinical cases (2002-2008). Vet. Ophthalmol. 12(1):17-24.

Raoufi M.F., Tajik P., Dehghan M.M., Eini F. \& Barin A. 2011. Isolation and differentiation of mesenchymal stem cells from bovine umbilical cord blood. Reprod. Dom. Anim. 46:95-99.

Seo M.S., Park S.B. \& Kang K.S. 2012. Isolation and characterization of canine Wharton's jelly-derived mesenchymal stem cells. Cell Transpl. 21:1493-1502.

Solomon A., Wajngarten M., Alviano F., Anteby I., Elchalal U., Pe'er J. \& Levi-Schaffer F. 2005. Suppression of inflammatory and fibrotic responses in allergic inflammation by the amniotic membrane stromal matrix. Clin. Exp. Allergy 35:941-948.

Uranio F.M., Valentini L., Lange-Consiglio A., Caira M., Guaricci A.C., L'Abbate A., Catacchio C.R., Ventura M., Cremonesi F. \& Dell'Aquila M.E. 2011. Isolation, proliferation, cytogenetic, and molecular characterization and in vitro differentiation potency of canine stem cells from foetal adnexa: a comparative study of amniotic fluid, amnion, and umbilical cord matrix. Mol. Reprod. Dev. 78:361-373.

Van Pham P., Truong N.C., Le P.T., Tran T.D., Vu N.B., Bui K.H. \& Phan N.K. 2015. Isolation and proliferation of umbilical cord tissue derived mesenchymal stem cells for clinical applications: cell tissue bank. DOI 10.1007/s10561-015-9541-6

Yuan H., Zhuang Y., Xiong J., Zhi W., Liu L., Wei Q. \& Han P. 2013. Human umbilical mesenchymal stem cells-seeded bladder acellular matrix grafts for reconstruction of bladder defects in a canine model. Plos One 8(11). Doi:10.1371/journal.pone.0080959

Zhang H.T. \& Fan J. 2010. Human Wharton's jelly cells can be induced to differentiate into growth factor-secreting oligodendrocity progenitor-like cells. Differentiation 15:15-20. 